\title{
Identification and Characterization of Bacterial Agents Causing Moderate Damage and Souring of the Fig Fruits
}

\author{
Seyedeh Asiyeh Mousavi ${ }^{1} \&$ Nader Hasanzadeh ${ }^{1}$ \\ ${ }^{1}$ Department of Plant Pathology, Faculty of Agriculture and Food Industries, Tehran Science and Research \\ Branch, Islamic Azad University, Tehran, Iran \\ Correspondence: Seyedeh Asiyeh Mousavi, Department of Plant Pathology, Faculty of Agriculture and Food \\ Industries, Tehran Science and Research Branch, Islamic Azad University, Tehran, Iran. E-mail: \\ asiyehmousavi67@gmail.com
}

Received: January 30, 2021

doi:10.5539/jps.v10n1p40
Accepted: March 6, $2021 \quad$ Online Published: March 21, 2021

URL: https://doi.org/10.5539/jps.v10n1p40

\begin{abstract}
In order to determine the factors of decay and sourness of fig fruits, in the summer of 2016-17, 60 leaf, fruit and stem samples from different regions of Tehran, Varamin (Qal'e No), Mazandaran (Amol, Noor and Sari), Lorestan from Iran and a branch of fig fruit sample from Italy were collected. We obtained 30 isolates from the sample. The pathogenicity of 30 isolates were confirmed by artificially inoculation using fig fruits. They were also characterized based on key phenotypic traits. All 30 isolates showed hypersensitivity reaction to tobacco, pelargonium and did not show pathogenicity to potato tubers. 16S rRNA gene of the 10 representative isolates were sequenced. Ten isolates were identified as Stenotrophomonas maltophilia, Pseudomonas aeruginosa, Pseudomonas fulva, Brevibacterium linens, Pseudomonas fragi, Bacillus licheniformis, Bacillus paralicheniformis and Bacillus cereus based on the determined sequences. None of the isolates caused fruit rot but typical disease symptoms were observed on fig leaves and fruits. This is the first report of the presence of pathogenic bacteria on fig trees in Iran.
\end{abstract}

Keywords: fig trees, bacteria, Iran, 16S rRNA gene, sequencing

\section{Introduction}

Among the agricultural products, fruits are the most important horticultural products that play an important role in supplying human nutrition and health. Among these, the fig (Ficus carica L.) is one of the earliest cultivated fruit trees in the world (Jalili Marandi, 2007). The tree is cultivated in warmest and temperate Mediterranean climates with fifty percent of the world's fig production concentrated in the Mediterranean area. Fresh and dried figs are consumed and appreciated worldwide not only for their unique taste and distinct flavor, but also for their health benefits. Figs have been popular not only because of their pleasant taste but possibly also because of their medicinal properties (Ercisli et al., 2012). The short postharvest life of fresh fruits is a critical point for the marketability in respect to dried fruits. The fresh figs are highly perishable fruits being susceptible to postharvest deterioration, such as softening, bruising, splitting, and pathogens growth (Adiletta et al., 2019). In Iran, Fars province and Estahbanat city are considered as the poles of fig production (Sabet Sarvestani and Faghih, 2001). According to the Agricultural Jihad statistics, 86685.5 hectares of dry and rainfed agricultural lands of the country were allocated to the commercial fig production (Agricultural Statistics, 2015). FAO statistics also show that Iran's rank in terms of production and cultivation of fig is fifth and third, respectively (FAO, 2012). Many biotic factors have been forced to reduce the production of figs in gardens and in warehouses. These include the fungi, Cercospora leaf spot (Cercospora fici), fig souring (Hanseniospora osmophila), fig brown rot (Fusarium moniliforme) and fig mosaic virus (unknown virus) (Sabet Sarvestani and Faghih, 2001; Palmateer et al., 2010). Some other fig fungal diseases include Botrytis blight (Botrytis cinerea), Thread blight (Pellicularia koleroga) results in necrosis of stems and matted foliage, Botryosphaeria dothidea which cause necrosis of leaves and stems and Rhizopus stolonifer (smut) as the causal of fruit drop of cultivars with an open eye. Fusarium spp. and Aspergillus niger are also attack ripe fruits (Anonymous, 2017).

Few bacterial diseases were also reported on Ficus spp. particularly on edible figs (Ficus carica). These include crown gall (Agrobacterium tumefaciens), Pseudomonas leaf spot (Pseudomonas cichorii) and Xanthomonas leaf spot caused by Xanthomonas campestris pv. fici (Campoverde and Palmateer, 2011; Henley and Poole, 2013). 
Rhizobium larrymoorei (=Agrobacterium larrymoorei) was isolated from gall of weeping fig (Ficus benjamina) (Bouzar and Jones, 2001).

Apart these, various yeasts, fungi, and bacteria apparently responsible for the souring disease of the fruit of the fig. Organisms are carried into the fruit by the dried fruit beetle, Carpophilus hemipterus. It is a preharvest problem resulting from yeasts and bacteria carried into the figs by insects, especially vinegar flies, resulting in odors of alcohol or acetic acid (Crisosto and Kader, 2004; Henley, 1991; Ferguson et al., 2011). Many types of fig fruit rot were observed, from the soft, watery, fermented type to the typical dry-rot type (Caldis, 1930). The aim of this study was to identify new bacterial pathogens and some bacteria affecting fruit souring of fig trees.

\section{Materials and Methods}

\subsection{Isolation and Purification of Bacteria}

In the summer and late autumn of 2016, 60 plant samples including branch, leaf and fruit of infected fig trees with brown spot symptoms on leaves and rot and deformity of fruits and necrotic spots on fruit and stems were collected from different regions of Tehran, Mazandaran and Varamin, Iran. A peculiar fig samples were collected from a tree grown in Modarres hospital yard in Tehran. All samples were washed with distilled water and then sterilized with $70 \%$ alcohol for 1 minute. Small pieces from border of infected and healthy tissue were prepared and each was transferred to tubes containing $5 \mathrm{ml}$ sterilized distilled water. A loopful of sample suspension was streaked on Nutrient agar (NA) and King's(KB) media. Petri plates was incubated at $25^{\circ} \mathrm{C}$ for 48 hours. The typical single colonies were transferred to new culture media and purified. Pathogenicity tests were fulfilled and all suspected pathogens were preserved in nutrient broth containing $15 \%$ glycerol at $-20^{\circ} \mathrm{C}$ and in NA slants under liquid paraffin.

\subsection{Identification Based on PCR Analysis}

\subsubsection{DNA Extraction}

Bacterial DNA was extracted by simple boiling method modified after Sambrook et al.,1989 (Elboutahiri et al.,2009). Bacteria were grown in agar media at $28^{\circ} \mathrm{C}$ for 2 days. A loopful of cells was suspended in $25 \mu 1$ of sterile distillated water and followed an addition of $25 \mu \mathrm{l}$ of freshly prepared lysis buffer containing $0.1 \mathrm{~N} \mathrm{NaOH}$

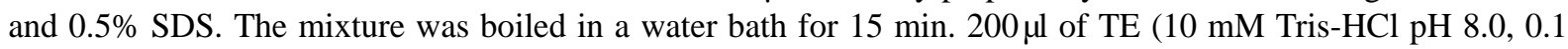
mM EDTA) was added to the mixture and centrifuged at 13,000 rpm for 5 minutes. Each supernatant was transferred to a clean tube and stored at $-20^{\circ} \mathrm{C}$.

\subsection{Preparation of Mixture Reaction for PCR Test}

The final volume of the reaction mixture was $25 \mu \mathrm{l}$ for each tube, containing $23 \mu \mathrm{l}$ of the reaction mixture and 1 $\mu \mathrm{l}$ of genomic DNA equivalent to100 ng for each isolate. The primer pair P1(5'-AGAGTTTGATCCTGGTCAGAACGCT-3') and P6 (5'-TACGGCTACCTTGTTACGACTTCACCCC-3') was used (Palacio-Bielsa et al., 2009). The reaction mix was placed on a thermocycler and subjected to PCR cycles: $94^{\circ} \mathrm{C}$ for $2 \mathrm{~min}$, followed by $94^{\circ} \mathrm{C}$ for 45 seconds, annealing at $58^{\circ} \mathrm{C}$ for 45 seconds, extension at a temperature of $72^{\circ} \mathrm{C}$ for 1 minute and final extension by 35 cycles at a temperature of $72^{\circ} \mathrm{C}$ for 20 minutes. PCR amplified products were electrophoresed in an agarose gel (1\%) and were visualized using loading buffer dye (Is it right? loading buffer dye is only a guide to adjust the time of electrophoresis. You can not see PCR product). PCR products of 10 strains were sent to Macrogen Inc. (Seoul, South Korea) for sequencing. Sequencing was done in both directions of Sense and Antisense using P1/P6 primers. Sequence similarity was determined using a BLAST search of the National Center for Biotechnology Information (NCBI).

Pathogenicity test on detached fig fruits and leaves:

The fruits and leaves of two fig varieties (desert King fig and Adriyatic fig) were first disinfected with alcohol and then were put into sterilized petri dishes containing sterile distilled water. The leaves and fig fruits were inoculated with individual bacterial suspension using straight wire (Schaad et al., 2001). Distilled water is used as a negative control. The negative treatments were checked daily for development of any disease symptoms.

Characterization based on pathogenicity to tobacco, pelargonium and potato tubers

1- Hypersensitivity reaction (HR):

Thirty isolates, which had been confirmed the capability of causing HR on tobacco leaves, were served for HR test to pelargonium leaves. At first, a suspension of bacteria with an approximate concentration of $10^{6} \mathrm{cfu} / \mathrm{ml}$ was prepared and then injected with a sterile syringe to underside of the young leaves of pelargonium. The reaction was evaluated for 24 to 48 hours (Klement, 1963). 


\section{2- Potato soft rot test:}

Healthy and fresh potato tubers were washed thoroughly with tap water, surface sterilized with $70 \%$ alcohol. The tuber skin was peeled and internal tissue was cut into small slices. Each slice was placed into sterile petri dish containing about $1 / 8$ inch of sterile water and the surface was of the tissues were inoculated with a single colony of each isolate using 10? 30? isolates. Distilled water was used as negative controls. Petri dishes were kept at 25-30 ${ }^{\circ} \mathrm{C}$ for 24-24 hours. All rotten and decay slices were recorded (Schaad et al., 2001).

\subsection{Phenotypic Characterization of the Isolates}

The 10 isolates were characterized based on certain key tests. These include, gram test, aerobic/anaerobic growth, $\mathrm{NaCl}$ tolerance, spore formation, fluorescent pigmentation, levan production, oxidase, catalase, gelatinase, amylase, $\beta$-glucosidase, urease and nitrate reductase tests. Citrate utilization, casein and tween hydrolyses, MR-VP tests were also tested (Schaad et al., 2001).

\section{Results}

\subsection{Isolation and Characterization of the Isolates}

Sixty fig plant samples with different diseased and abnormal symptoms from 7 cities from Iran and one from Italy were collected (Fig. 1). Thirty bacterial isolates were selected in the first stage that were capable of causing HR on tobacco leaves and to some extent disease symptoms of fig leaf and fruit. Of these, 10 isolates with sever disease symptoms were selected for PCR analysis.

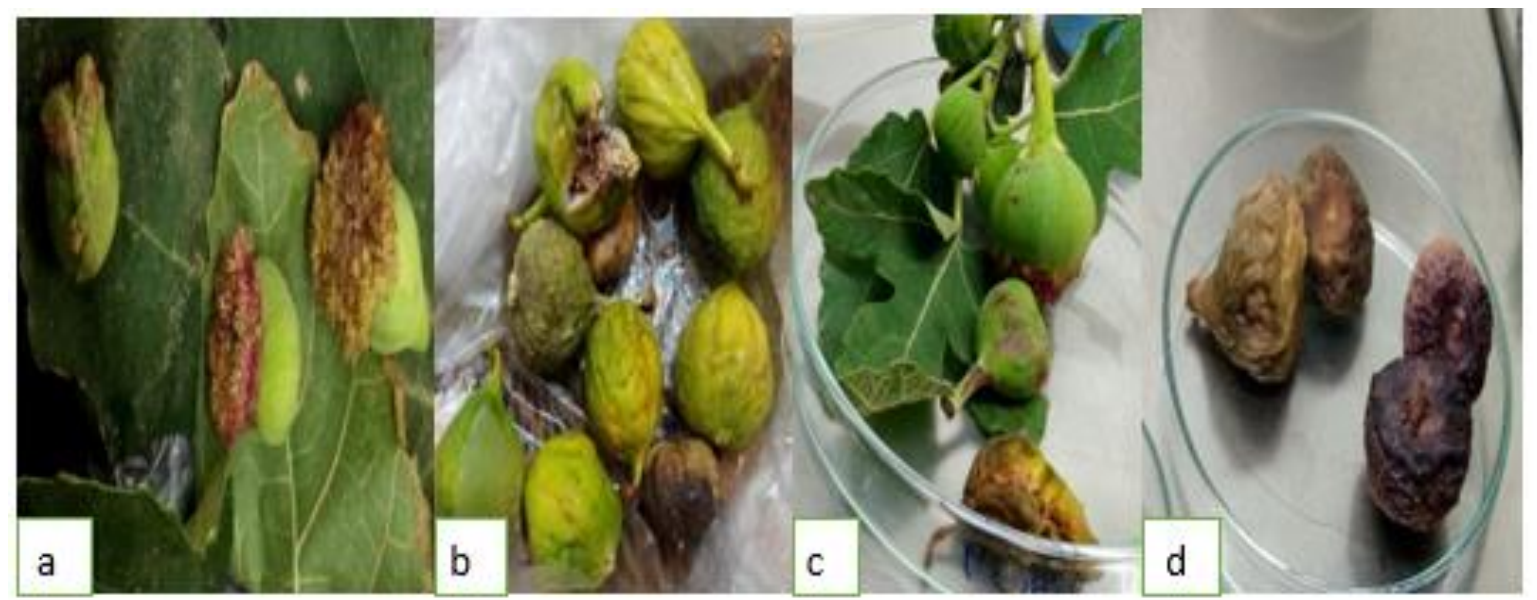

Figure 1. Fig fruits and leaves suspected of bacterial contamination collected from different regions. a) fig fruit deformation, b) wrinkling and sagging of fig fruit, c) brown spots on figs fruits, d) fig fruit soreness and wrinkles

\subsection{Determination of the 16S rDNA Gene Sequences}

All 10 selected bacteria produced a single sharp 1500bp fragment (Figure 2). The result were indicated that the strains AM2, AM5 and AM11 by $100 \%$ of homology were belonged to Stenotrophomonas maltophilia, Bacillus paralicheniformis and Pseudomonas fragi, respectively. Likewise, the strains AM13, AM15 and AM26, AM22 and AM27 by $100 \%$ of homology were assigned as Bacillus licheniformis, Serratia marcescens, Pseudomonas aeruginosa and Bacillus cereus, respectively. Percentage of homology $96 \%$ and $84 \%$ ensured that The 16S rRNA gene sequences of the strains AM12 and AM18 were also showing $96 \%$ and $84 \%$ identity to Brevibacterium linens and Pseudomonas fulva, respectively.

Their GenBank accession numbers of the strains are as follows: MH001477, MH012180, MH012187, MH012195, MH012196, MH012198, MH013188, MH014944, MN461457 and MN461460. 


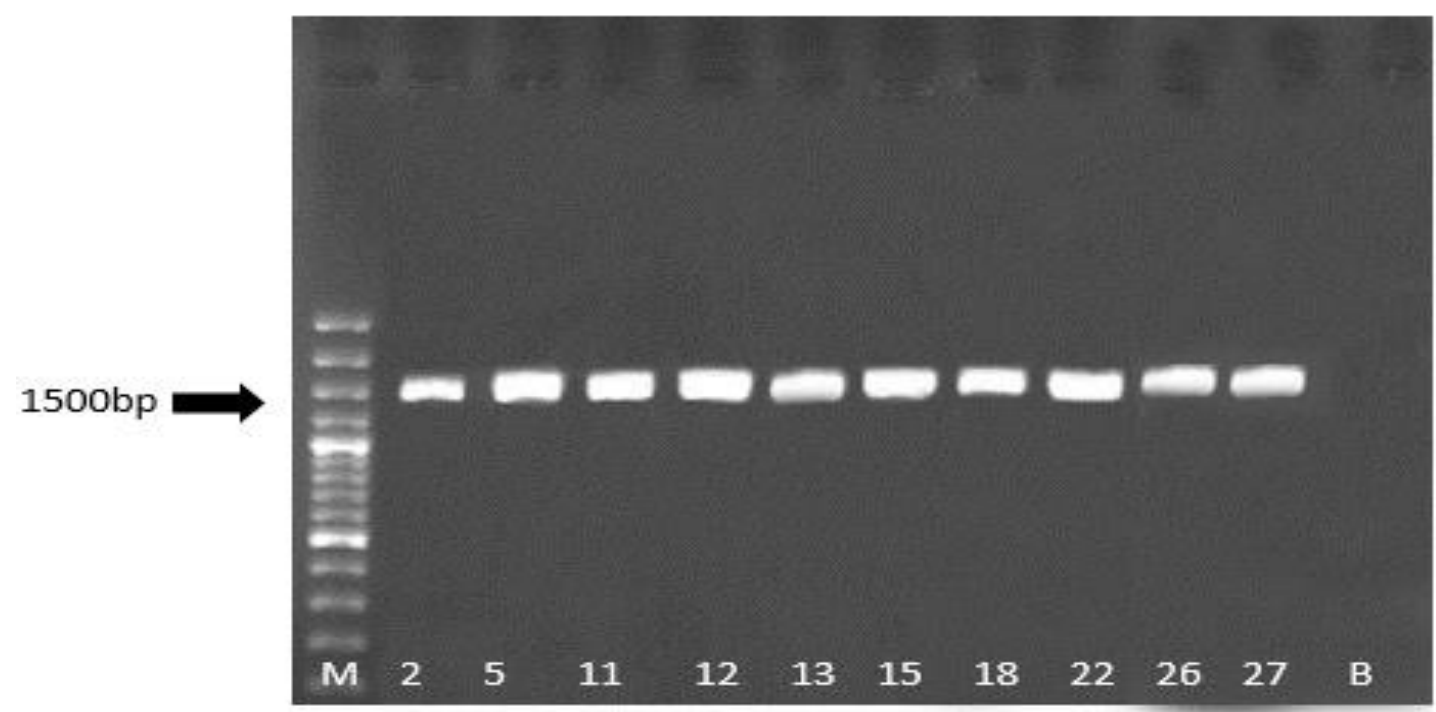

Figure 2. A PCR amplification products of $1500 \mathrm{bp}$ for all 10 selected strains

Lane designations: M, 100 bp ladder; 2) Stenotrophomons maltophilia AM2; 5) Bacillus licheniformis AM5; 11) Pseudomonas fragi AM11; 12) Brevibacterium linens AM12; 13) Bacillus paralicheniformis AM13; 15) Serratia marcescens AM15; 18) Pseudomonas fulva AM18; 22) Pseudomonas aeruginosa AM22; 26) Serratia marcescens AM26; 27) Bacillus cereus AM27.

\subsection{Pathogenicity Tests}

\subsubsection{Testing for Pathogenicity on Fig Fruits and Leaf}

All 10 selected isolates caused various disease symptoms including necrosis and chlorosis in leaves; rot and deformity of fruits and brown spots on fruit skin and stem on fig fruits. Pseudomonas aeurginosa isolate AM22 caused the wrinkling of the fruits, as it had been seen in natural conditions. On the other hand, Serattia marcescens isolates AM15 and AM26, Brevibacterium linens isolate AM12, Stenotrophomonas maltophilia AM2 and Pseudomonas fragi isolate AM11, caused brown spots, water-soaking lesions and fruit spoilage. The three more isolates namely Bacillus licheniformis AM13, Pseudomonas fulva AM18 and Bacillus paralicheniformis AM5 could cause brown spots and water-soaking lesions without fruit spoilage (Fig.3).

The four bacteria namely, Pseudomonas fragi, Brevibacterium linens, Serratia marcescens, Pseudomonas aeruginosa could have severe symptoms of the disease on Adriatic fruits rather than desert king fig fruits.

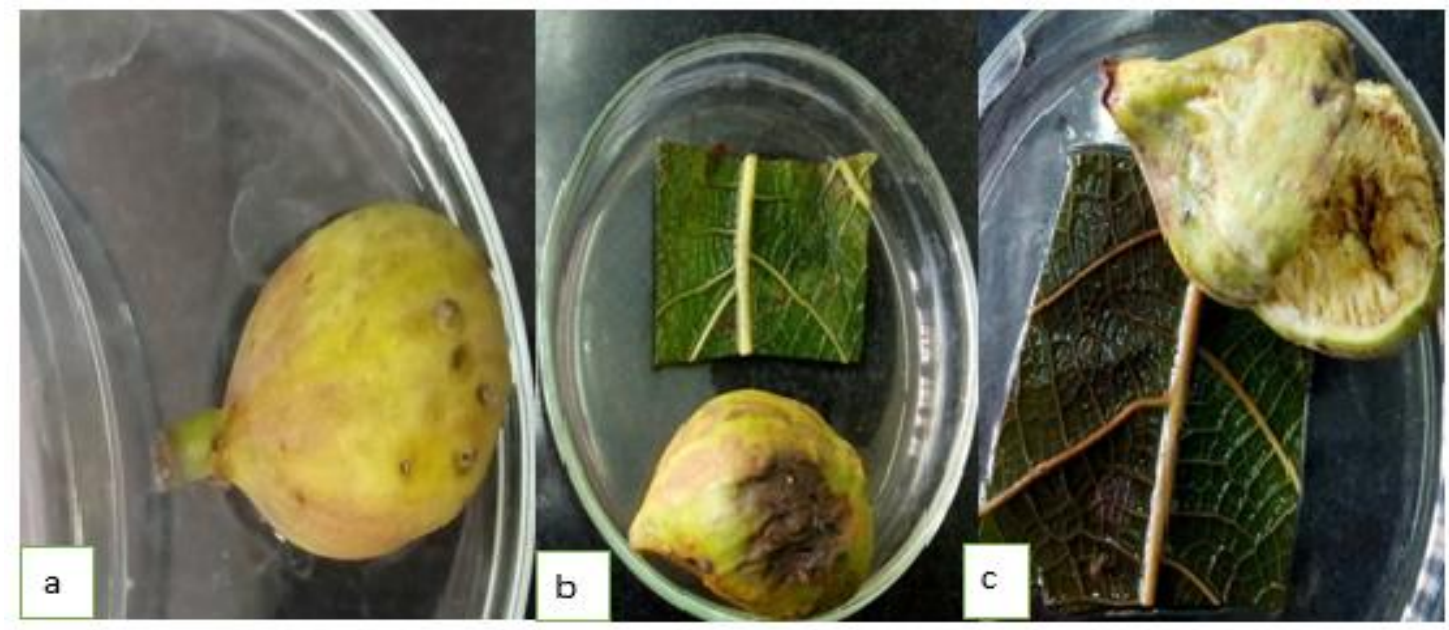

Figure 3. Incidence of necrosis and chlorosis symptoms on leaves and fruits by isolates a) Stenotrophomons maltophilia strain AM2, b) Pseudomonas aeruginosa strain AM22, c) Brevibacterium linens strain AM12 


\subsubsection{Hypersensitivity Reaction}

All 30 isolates tested were able to cause hypersensitivity and necrosis on pelargonium leaves (Fig. 4).
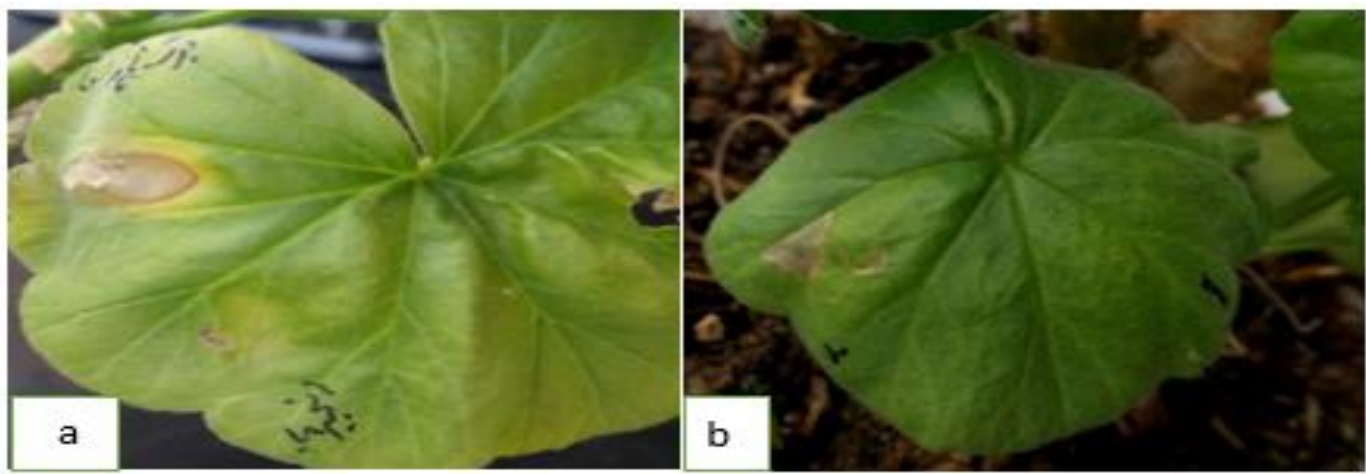

Figure 4. The two representative isolates that caused necrosis symptoms on pelargonium leaves

a) Stenotrophomonas maltophilia strain AM2, b) Serratia marcescens strain AM15.

\section{2- Potato soft test:}

None of the 30 isolates that showed necrosis on the pelargonium leaves were able to soft rot on the potato slices.

\subsection{Identification of Bacterial Isolates}

The ten selected bacteria were identified based on certain morphological, physiological and biochemical tests (Table 1).

Table 1. Morphological, physiological and biochemical tests for differentiating 10 selected fig fruits

\begin{tabular}{lllllllllll}
\hline Isolates & 1 & 2 & 3 & 4 & 5 & 6 & 7 & 8 & 9 & 10 \\
\hline Chamacteristic & & & & & & & & & & \\
Colony color & - & + & - & + & + & - & - & - & - & + \\
Fluorescent pigment on KB & + & - & + & - & - & - & - & + & - & - \\
O/F test & $\mathrm{Y}$ & $\mathrm{W}$ & $\mathrm{W}$ & $\mathrm{C}$ & $\mathrm{W}$ & $\mathrm{W}$ & $\mathrm{Y}$ & $\mathrm{M}$ & $\mathrm{W}$ & $\mathrm{W}$ \\
Nitrate reduction & + & $\mathrm{F}$ & $\mathrm{O}$ & $\mathrm{O}$ & $\mathrm{F}$ & $\mathrm{F}$ & $\mathrm{O}$ & $\mathrm{O}$ & $\mathrm{F}$ & $\mathrm{F}$ \\
Nitrate reduction & + & + & - & + & + & + & - & + & + & + \\
Arginine dihydrolase & - & - & + & + & - & - & + & + & - & - \\
Arginine dihydrolase & - & + & - & + & + & + & - & + & + & + \\
Hydrolysis: Starch & - & + & - & - & + & - & - & + & - & + \\
Gelatin & + & - & - & + & - & + & - & + & + & - \\
Tween 80 & + & - & + & - & - & + & - & + & + & - \\
Levan production & - & - & - & - & - & - & - & - & - & - \\
Potato soft rot & - & - & - & - & - & - & - & - & - & - \\
HR on geranium & + & + & + & + & + & + & + & + & + & + \\
\hline
\end{tabular}

1) Stenotrophomons maltophilia strain AM2; 2) Bacillus licheniformis strain AM5; 3) Pseudomonas fragi strain AM11; 4) Brevibacterium linens strain AM12; 5) Bacillus paralicheniformis strain AM13; 6) Serratia marcescens strain AM15; 7) Pseudomonas fulva strain AM18; 8) Pseudomonas aeruginosa strain AM22; 9) Serratia marcescens strain AM26; 10) Bacillus cereus strain AM27.

M: milky; Y: yellow; C: creamy; W: white; O/F; O: aerobe; F: facultative anaerobe.

You identified based on sequence similarity.

\section{Discussion}

Despite the importance of fig for Iran, which is economically valuable, the bacterial diseases of the fig trees, has remained silent until now. Perhaps one of the reasons is that there are a few reports of bacterial diseases on this host worldwide. Most diseases are caused by fungi and most prevalent fruit infection is souring which has been caused by various yeasts, fungi, and bacteria, carried into the fruit by the dried fruit beetle, Carpophilus 
hemipterus (Cladis,1930; Crisosto and Kader, 2004).

In this research, we obtained 60 fig fruits isolates from seven cities in Iran and one city in Italy.

The distribution of these bacteria and the areas where these isolates were isolated are as follows: P. aeruginosa and $S$. marcescens were isolated from leaf and fruits of the fig trees located in Modarres hospital in Tehran. $P$. fragi and S. maltophilia were isolated from leaves and ripe fruits of fig trees in green space of Varamin Research Institute, respectively.

S. maltophilia and B. paralicheniformis were isolated from ripe fruits and leaves of figs trees in Varamin city, respectively. P. fulva from leaf and B. linens from fruit samples of Amol city. B. licheniformis was the only isolate which was collected from Eram Park-Tehran. Among these, B. cereus was the only isolate obtained from a single fig sample of the Bari-Italy. An important finding in this study was the isolation of Serattia marcescens, Stenotrophomonas maltophilia, Pseudomonas aeruginosa, Pseudomonas fulva, Bacillus licheniformis, Bacillus cereus as common bacteria in humans and plants from fig trees in different regions.

According to numerous reports, these bacteria cause an infection in humans, especially in patients with immune deficiency (Claus,1986; Aslani, 2009). It was reported by Kamar, 1989 that Bacillus cereus is the cause of two types of poisoning (diarrhea and vomiting). In the case of Brevibacterium linens and Pseudomonas fragi, these two species have been isolated from plant and dairy products and have been caused the consumer illness (Pereira, 1957). Whereas, Pseudomonas fragi was isolated from lettuce (Edelman and Lin, 2014). Pseudomonas aeruginosa, a common opportunistic bacterium between humans and plants was isolated from diferent sources such as rhizosphere of corn (Tahmasebi et al., 2014) and tobacco leaf in China (Yu, 2008). Another important species was Pseudomonas fulva, a clinical isolate which has been reported mostly from aquatic environments including rice seed and fennel plants (Edelman and Lin, 2014). Serattia marcescens, a ubiquitous bacterium has been isolated from plant materials such as watermelon (Hosseini et al., 2013) and nutty trees (Habibi and Khodaygan, 2013). The latter, was first isolated from figs in New York (Edelman and Lin, 2014).

Bacillus licheniformis, has a wide range of hosts and is isolated from soil containing vegetable waste (Nagaraju, 2013), wheat fields of central provinces, Golestan and Mazandaran (Etebarian et al., 2008), cucumber farrowing in Jiroft (Rezaei et al., 2016), soil and water around the hot springs in Semnan (Moghbeli and Noshiri, 2009). Bacillus paralicheniformis like most of the above bacteria, has been isolated on various plants rather than the figs. For example, from soybean paste (Christopher, 2015), soil containing citrus waste soil in several regions of Golestan province (Mohammadi et al., 2016), wheat fields of central provinces of Golestan and Mazandaran (Etebarian et al., 2008), rhizosphere of orange trees in Kerman province (Ramezani et al., 2013) and also from asparagus plant in Iran (Faghanizadeh et al., 2016) and in New York (Edelman and Lin, 2014).

In conclusion, it should be noted that all bacteria except Serratia marcescens are reported for the first time on fig plants in Iran. There is no doubt that water, food and vegetables play an important role in the spread of pathogens and secondary infections. Given that some of these causal agents are transmitted through consumption of fresh fruits and vegetable, planting fruit trees in open gardens of hospitals is a major mistake and potentially very dangerous for the incidence and spread of diseases with a common human-plant hosts. And finally, due to the abundance of microbial populations in soft rot and damaged fruits, their consumption should be avoided to maintain the health of the body.

\section{References}

Adiletta, G., Coletta, C., \& Petriccione, M. (2019). Chitosan Coating to Preserve the Qualitative Traits and Improve Antioxidant System in Fresh Figs (Ficus carica L.). Agriculture, 9, 84. https://doi.org/10.3390/agriculture9040084

Agricultural Statistics. (2015). Ministry of Jihad-e-Agriculture - Planning and Economic Deputy. Horticultural products (unfertilized and fertile levels, yields and yields broken down by water and rain). pp. 29-31.

Anonymous. (2017). Fig diseases. pp. 1.

Aslani, M., Hahsemipour, M., Sadat Nikbin, V., Shahcheraghi, F., Eidi, A., \& Sharafi, Z. (2009). PCR identification of Pseudomonas aeruginosa based on two outer membrane lipoprotein oprI, oprL, and exotoxin A gene. Yafteh, 11(2), 29-23.

Bouzar, H., \& Jones, J. B. (2001). Agrobacterium larrymoorei sp. nov., a pathogen isolated from aerial tumours of Ficus benjamina. International Journal of Systematic and Evolutionary Microbiology, 51, 1023-1026. https://doi.org/10.1099/00207713-51-3-1023

Campoverde, E. V., \& Palmateer, A. J. (2011). A severe outbreak of Xanthomonas on Ficus elastica in South 
Florida. Proc. Fla. State Hort. Soc., 124, 321-322.

Caldis, P. D. (1930). Souring of gigs by yeasts and the transmission of the disease by insects. Journal of Agricultural Research, 40(11), 1931-1951.

Claus, D., \& Berkeley, R. C. W. (1986). Genus Bacillus Cohn, 1872. In P. H. A. Sneath, N. S. Mair, M. E. Sharpe, \& J. G. Holt (Eds.), Bergey's Manual of Systematic Bacteriology (pp. 1105-1139). The Williams \& Wilkins Co., Baltimore.

Crisosto, C. H., \& Kader, A. A. (2004). Fig. In K. C. Gross, C. Y. Wang \& M. Saltveit (Eds.), The Commercial storage of fruits, vegetables, and florist and nursery stock. USDA, ARS, Agricultural Hdbk. 66. Washington DC. Retrieved from http://www.ba.ars.usda.gov/hb66/115prickly.pdf

Christopher, A., Dunlap Soon-Wo, K., Alejandro, P. R., \& Soo-Jin, K. (2015). Bacillus paralicheniformis sp. nov., isolated from fermented soybean paste. International Journal of Systematic and Evolutionary Microbiology, 65, 3487-3492. https://doi.org/10.1099/ijsem.0.000441

Edelman, J. R., \& Lin, Y. J. (2016). Microbiology (Endobacteriology) of fruit and vegetable crops: An expanded and continuing study. International Journal of Nutrition and Food Sciences, 5(2), 95-104. https://doi.org/10.11648/j.ijnfs.20160502.12

Elboutahiri, N., Thami-Alami, I., Zaid, E., \& Udupa, S. M. (2009). Genotypic characterization of indigenous Sinorhizobium meliloti and Rhizobium sullae by rep-PCR, RAPD and ARDRA analyses. African Journal of Biotechnology, 8(6), 979-985.

Ercisli, S., Tosun, M., Karlidag, H., Dzubur, A., Hadziabulic, S., \& Aliman, Y. (2012). Color and antioxidant characteristics of some fresh fig (Ficus carica L.) genotypes from northeastern turkey. Plant Food Hum. Nutr., 67, 271-276. https://doi.org/10.1007/s11130-012-0292-2

Etebarian, H., Mohamadifar, M., Alizade, H., Zarisarabi, A., \& Taheri, P. (2008). Biological control of barley by antagonist bacteria. Journal of Pests and Plant Diseases, 74(2), 81-91. https://doi.org/10.1007/978-1-4020-6738-9_6

Faghanizadeh, V., Arzanesh, M., Yazdansetad, S., \& Nezamzadeh, R. (2016). Isolation and molecular characterization of endophytic bacteria from peppermint, chamomile, asparagus and antagonistic effect of isolates on fungal plant pathogens. Biological Journal Microorganisms, 19, 171-182.

Ferguson, L., Erguson, L., Bremer, V., \& Colelli, G. (2011). Fig (Ficus carica L.). In M. Yahia Elhadi (Ed.), Postharvest biology and technology of tropical and subtropical fruits (pp. 134-158). Woodhead Publishing Limited, Cambridge, UK. https://doi.org/10.1533/9780857092885.134

FAO. (2012). Satistical Database. Retrieved from htpp://faostat.Fao.Org

Habibi, H., \& Khodaygan, P. (2013). Identification of pathogenic bacteria with nucleus, grainy and walnut fruit trees in Alborz province. Msc thesis. Valiasr University of Rafsanjan. pp. 83.

Hosseini, M., Tarighi, S., \& Taheri, P. (2013). Isolation of Serratia marscecence isolates from pollinated watermelon fruits with watermelon fruit stinging disease. The 8th Biotechnology Conference of the Islamic Republic of Iran and the 4th National Bioethics Conference. pp. 4.

Henley, D. (1991). An Overview of Ficus for interior landscapes. Greenhouse Manager, 9(9), 62, 64-66, 68.

Henley, R. W., \& Poole, R. T. (2013). Ornamental Ficus diseases: identification and control in commercial greenhouse operations. PP308. Plant Pathology Department, UF/IFAS Extension. pp. 6. https://doi.org/10.32473/edis-pp308-2013

Jalili, M. (2005). Small Fruits (2 ed.). Urmia University Press. pp. 297.

Klement, Z. (1963). Rapid detection of the pathogenicity of phytopathogenic Pseudomonas. Nature, 199, 299-300. https://doi.org/10.1038/199299b0

Kramer, J. M., \& Gilbert, R. J. (1989). Bacillus cereus and other Bacillus species. In M. P. Doyle (Ed.), Foodborne bacterial pathogens (pp. 21-70). Marcel Dekker, Inc., New York, N.Y.

Mohammadi, R., Dadgar, T., Pardeli, H., Yazdansetad, S., Najafpour, R., \& Faraj tabrizi, E. (2016). Molecular isolation and characterization of Bacillus cereus and Bacillus subtilis as pectinase enzyme producers from different regions of Golestan province. Journal of Cell and Molecular Research, 29(3), 340-348.

Moghbli, M., \& Noshiri, H. (2009). Isolation of a native strain of Bacillus licheniformis producing alpha-amylase from warm sources of Semnan province. Journal of the World of Microbes, 2(3), 155-160. 
Nagaraju, V., \& Divakar, G. (2013). Screening and isolation of pectinase producing bacteria from various regions in Bangalore. International Journal of Research in Pharmaceutical and Biomedical Sciences, 4(1), 151-154.

Palacio-Bielsa, A., Cambra, M. A., \& Lopez, M. M. (2009). PCR detection and identification of plant-pathogenic bacteria: updated review of protocols (1989-2007). Journal of Plant Pathology, 91, 249-297.

Palmateer, A. J., Tarnowski, T. L. B., \& Roberts, P. D. (2010). Florida plant disease management guide: Fig (Ficus carica). IFAS, University of Florida. PDMG-V3-14.

Pereira, J. N., \& Morgan, M. E. (1957). Nutrition and physiology of Pseudomonas fragi. J Bacteriol, 74(6), 710-713. https://doi.org/10.1128/JB.74.6.710-713.1957

Ramezani, M., Riahi madvar A., \& Khaleghi, M. (2013). Isolation of Bacillus cereus producing $\alpha$-amylase from rhizosphere of orange trees. The World of Germs, the 6th issue of the second issue (15th session). pp. 168-177.

Rezaei, R., Alizadeh, H., Azadvar, M., \& Salari, K. H. (2016). Biocontrol properties of Bacillus species isolated from cranberry rosacea against Sclerotinia sclerotiorum. Biological Containment in Plant Protection, 4(2), 85-98.

Sambrook, J., Fritsch, E. F., \& Maniatis, T. (1989). Molecular Cloning: A Laboratory Manual (2nd ed.). Cold Spring Harbor Laboratory Press, New York. pp. 1656.

Sabet Sarvestani, J., \& Faghih, H. (2001). Fig planting, having, harvest. Publishing House of Raqushah publishing house, Shiraz. pp. 292.

Schaad, N. W. (1988). Laboratory Guide for Identification of Plant Pathogenic Bacteria (2 ed.). API Press. pp. 158.

Tamura, K., Stecher, G., Peterson, D., Filipski, A., \& Kumar, S. (2013). MEGA6: Molecular Evolutionary Genetics Analysis Version 6.0. Molecular Biology and Evolution, 30, 2725-2729.

https://doi.org/10.1093/molbev/mst197

Tahmasebi, F., lakziyan, A., Khavazi, K., \& Pakdin Parizi, A. (2014). Isolation, characterization and evaluation of siderophore production in Pseudomonas bacteria and its effect on maize growth in aqueous media. Journal of Cellular and Molecular Research, 27(1), 75-87.

Yu, L., Qin, X. Y., Du, J., Wang, A. Y., Zhao, Y. Y., Shen, D. J., Sun, Y. X., \& Huang, Q. (2008). Bacterial leaf spot of tobacco caused by Pseudomonas aeruginosa in China. Plant Pathology, 57(4), 774-774. https://doi.org/10.1111/j.1365-3059.2008.01876.x

\section{Copyrights}

Copyright for this article is retained by the author(s), with first publication rights granted to the journal.

This is an open-access article distributed under the terms and conditions of the Creative Commons Attribution license (http://creativecommons.org/licenses/by/4.0/). 